\title{
DIE PU VIR CHO SE NAAM, LEUSE EN TAAK IN DIE LIG VAN PSALM 36 ;
}

\author{
J.L. Helberg \\ Departement Ou Testament \\ Potchefstroomse Universiteit vir CHO \\ POTCHEFSTROOM
}

\begin{abstract}
In this article the motto and the name of the Potchefstroom University for Christian Higher Education are discussed against the background of Psalm 36 from which the motto is derived. This motto consists of the words "In thy light", or "In thy light we see the light". The lask resulting from this motto and this name is also considered. Attention is paid to the unity between the Old and the New Testament, the relation between God as Creafor and as Redeemer, and between Scripture/faith and science. The relation between the translations "In thy light we see the light" and "through thy light we live", as well as the relation between the "secular" opplication of Psalm 36:10 as University motto and the cultic setting is investigated. The ethical antithesis in the Psalm is also discussed. Scholarship in the spirit of senving God and one's neighbour with one's whole being is stressed.
\end{abstract}

\section{INIEIDEND}

Die gedeelte van die naam waarom dit in hierdie artikel gaan, is die woorde "vir Christelike Hoër Onderwys"; en die leuse is: "In u lig", of volledig weergegee, "In u lig sien ons die lig". Hierdie leuse is uit Psalm 36:10 geneem. Die artikel word beperk tot die naam en die leuse en tot die taak wat daaruit voortvloei. Die bespreking raak veral die volgende vier krities gestelde vrae:

- Die leuse van die Universiteit kom uit die Ou Testament; die Naam van die Universiteit daarenteen, verwys na "Christelike" onderwys en grond die Universiteit in die Nuwe Testament. Die vraag kan weliswaar gevra word of dit klop om so op twee Testamente gegrond te wees - op 'n oue en 'n nuwe. Verder kan gevra word of dit verantwoord is om Christus, en dus verlossing, by wetenskapsbeoefening ter sprake te bring.

\footnotetext{
1 Hierdie artikel is ' $n$ verwerking van 'n voordrag gelewer by die gradeplegtigheid van die
} fakulteit Teologie en Regie van die PU vir CHO op 20 Maart 1990. 
* Ook kan gevra word of die leuse nie op 'n vergissing berus nie, aangesien die Nuwe Afrikaanse Bybelvertaling (1983) lui: "Deur u lig lewe ons". Hiervolgens slaan die sien van lig in Psalm 36:10 op bestaan, lewe, nie op kennis nie. Het die Universiteit se leuse nie met hierdie vertaling wesenlik in die slag gebly nie? Hierdie vraag het nog skerper relief gekry toe die eerste oplaag van die Blye Boodskap in 1975 verskyn het - die gedeelte oor lig het heeltemal weggeval in die teks. Weens 'n drukfout het die woorde "u lig" weggeval en het die teks net gelui: " $U$ is die bron van die lewe, skenk ons die lewe." Dit moes gelui het: " $U$ is die bron van die lewe, u lig skenk ons die lewe" - soos dit op daardie stadium van die vertaling nog vertaal was. (In Die Nuwe Testament en die Psalms, wat in 1979 verskyn het, is die laaste sinsnede gewysig na: "Deur u lig lewe ons".)

- Die universiteitsleuse is gekies uit 'n Skrifgedeelte wat blykbaar gerig is op die erediens. Word daarmee nie iets wat vir die erediens bedoel is, ten onregte op die wetenskap oorgedra nie?

- Psalm 36 is sterk antiteties; dit stel 'n sterk teenstelling met "die goddeloses". Die vraag is nou of die ontlening van 'n universiteitsleuse aan so 'n psalm nie meebring dat 'n antitese op die universiteit oorgedra word wat nie daar op sy plek is nie en wat gepaard gaan met 'n gees van onverdraagsaamheid teenoor andersdenkendes of berus op ' $n$ gees van selftevredenheid. Verder kan gevra word of 'n moreel-etiese basis relevant is vir 'n universiteit, byvoorbeeld vir die natuurwetenskappe. Behoort dit nie vir 'n universiteit te gaan om 'n andersoortige, 'n meer universele of holistiese benadering wat eerder die geheel van die werklikhede moet oopmaak nie?

Om hierdie vrae te beantwoord, moet op verskeie sake gelet word. Eerstens, die PU vir CHO gaan daarvan uit dat God Hom openbaar in die skepping (natuur) en in sy Woord, soos byvoorbeeld gestel in Psalm 19 (vgl. Calvyn, 1984:138-153 oor die verhouding van die Bybel en die skepping of natuur) - daarom word die leuse en grondslag in die Bybel as gesagvolle Woord van God gevind. Verder moet daar eers gekyk word na die tema van hierdie psalm en na die soort en aard van die Bybelse stof waaruit die leuse geneem is. Om dit te kan doen, sal daar vlugtig op die inhoud van die psalm in sy geheel ingegaan moet word en sal ook na die verhouding tussen die Ou Testament en die Nuwe Testament gekyk moet word. 


\section{DIE TEMA, SOORT EN AARD VAN PSALM 36}

Volgens Schmidt (1934:67-68) is vers 2-5 saam met vers 13 en vers 6-12 oorspronklik as afsonderlike liedere beskou. Ook Taylor (1955:187) sien dit so. Hy meen dat die literêre verwantskap tussen die twee gedeeltes van die psalm so swak is dat hulle blykbaar oorspronklik onafhanklike eenhede was. Een of ander redakteur het egter die twee gedeeltes saamgegroepeer omdat hulle in skerp relief die twee botsende leefwyses geteken het: dié van die man wat met die bose omgaan en dié van die man wat sy vreugde vind in nadenke oor God. Die tweede deel is daarom die aanvulling van die eerste en die hele psalm kom in die geselskap van Psalm 1,10 en 73 te staan.

Indien ' $n$ mens die ware aard van die psalm begryp, is dit egter onnodig om so 'n saamgestelde outeurskap te aanvaar (vgl. Oesterley, 1959:219; Ridderbos, 1955:309; Weiser, 1959:205; Kraus, 1972(a):281-282). Die tema handel oor God se trou in 'n wêreld vol selfvoldane goddeloosheid. Of anders gestel - die psalm sê: alleen by God is daar lig, ware lewe, in 'n wêreld waarin die mens die sin en bron in homself soek.

Kraus (1972(a):282) sê tereg dat dit kwalik moontlik is om die slotvers (v.13) aan 'n sogenaamde $36 \mathrm{~A}$ toe te skryf, aangesien so 'n literêr-kritiese stelling geen saaklike gronde het nie. Dat die psalm 'n eenheid is, word bewys deur die teenoormekaarstelling van die bedreiging (v. 2-5) en die asielfunksie van die heiligdom (v. 8), wat beskerming en vreugde verleen.

Verder blyk die eenheid van die psalm daaruit dat die slotvers weer aansluit by die goddelose wat in die gesketste kultiese situasie as donker agtergrond dien waarteen die ligtende beeld van die Goddelike goedheid geteken word (vgl. Weiser, 1959:205-206). Die slotgedeelte (v. 11-13) gryp dan ook nie net terug op vers 2-5 nie maar ook op die tweede gedeelte. Dit gebeur ook nie net in vers 13 nie maar reeds in vers 12 in die digter se beroep op God se beskerming teen die goddeloses (vgl. Ridderbos, 1955:309). Tournay (1983:5-22) verwys vir die eenheid van die psalm na ooreenkomste met die eerste hoofstukke van Genesis, naamlik in die gebruik van polêre uitdrukkings en antiteses (soos goed en kwaad).

'n Verdere aanduiding van die eenheid van die psalm is die teenstelling wat vers 11 maak met die goddelose in vers 2 (vgl. ook v.12). Die goddelose "vrees" God nie (v. 2) en ken God daarom ook nie, want om die Here te vrees is die beginsel van die kennis so sê die wysheidsliteratuur in die Ou Testament (vgl. bv. Job 28:28; Spr. 1:7; Pred. 12:3; Ps. 111:10). Daarenteen is die goddelose op pad na die afgrond (vgl. Ps 1:1,6). 
Psalm 36 is 'n gedig. Digterlike stof word nie gewoon letterlik gelees soos byvoorbeeld 'n inkopelys, of ' $n$ bundel wette, of 'n verhaal nie. Digterlike materiaal maak op ' $n$ ander manier van begrippe en voorstellings gebruik om gedagtes of waarhede tuis te bring. Dit sluit byvoorbeeld soms wan by mitologiese voorstellings of beelde sonder om die beskouing wat daarin vervat is, oor te neem. 'n Voorbeeld hiervan is die seemonster Ragab of Tiamat of Leviatar. wat volgens 'n ou Oosterse beskouing by die skepping verslaan sou gewees het (vgl. Van Selms, 1967:44; Kraus, 1972(b):714; Helberg, 1988a:48). 'n Moontlike voorbeeld van 'n mitologiese verwysing in Psalm 36 is die uitdrukking "berge van God" (36:7), waarop hier vir ons doel nie nader ingegaan hoef te word nie (vgl. vir die voorstellings, Oesterley, 1959:220). Die digterlike aard van Psalm 36 hou in dat dit wat daarin gesê word, nie regstreeks op vandag of meer bepaald, op 'n universiteitsituasie betrek kan word nie. Daar moet rekening gehou word met die eintlike doel van die psalmdigter.

Wat die presiese aanleiding vir die ontstaan van die psalm was, is nie duidelik nie (vgl. byvoorbeeld Ridderbos, 1955:310; Kraus, 1972(a):281). Wel is dit duidelik dat die gedig te midde van bedreiging ontstaan het, persoonlike bedreiging of groepsbedreiging, of albei. Hierdie soort bedreiging kom dikwels in die psalms voor (vgl. Ridderbos, 1955:392). Die psalm getuig van 'n basiese bedreiging in die digter se bestaan - trouens dit getuig daarvan dat bedreiging 'n basiese deel van menswees is (vgl. Ridderbos, 1955:408; Kraus, 1972(a): LXXV; Balentine, 1989:610). In die lig hiervan kan die gedig ook ter sake wees vir situasies anders as diê van die digter, aangesien hy tot nadenke gekom het oor die diepe sin van dinge.

Psalm 36 vertoon kenmerke van drie soorte liedere, die sogenaamde klaaglied, die loflied en die wysheidslied (vgl. byvoorbeeld Kraus, 1972(a):281). Die benaming klaaglied het nie die negatiewe betekenis soos by ons nie en dui nie op 'n vervelige en pessimistiese relaas nie. Die ware Bybelse klaaglied is 'n gebed waarin die bidder sy nood en behoefte voor God stel en by God om uitkoms smeek, of selfs met God om uitkoms worstel. Dié lied word dikwels gedra deur 'n ondertoon van vertroue en vertoon ook kenmerke van dankbaarheid. Dit geld ook vir Psalm 36.

'n Loflied in die Ou Testament is 'n spontane uiting van lof aan God oor sy hoedanighede of optrede soos sy mag, sy reddingsdade, sy goedheid en sy trou. Die klaaglied en die loflied vorm saam die hoofgroep van liedere, en dit hang saam met die feit dat droefheid en vreugde die hoofstemminge van 'n mens se lewe uitmaak. Hier in Psalm 36 gaan dit om die droefheid wat goddeloosheid en onreg in die mense se lewe veroorsaak en om lof oor God se liefde. Die psalm word beheers deur die trou van God en vertolk 'n positiewe en vertrouensvolle lewensbenadering te midde van die werklikheid 
van die kwaad en die onreg wat hom in alle fasette van die lewe as geheel vertoon.

Veral Psalm 36:2-5 bevat uitdrukkings wat kenmerkend is van die wysheidsliteratuur en wat tot die woordeskat van Spreuke behoort, naamlik, "die vrees van Jahwe", "verstandig wees", "n pad wat nie reg is nie". Die karaktertekening van die goddelose mens vertoon ooreenkomste met dié in Job (vgl. Taylor, 1955:188; Kraus, 1972:282; vir moontlike linguistiese maatstawwe om wysheidselemente in die psalms te bepaal, vgl. Hurvitz, 1988:41-55. Vergelyk verder Thomas, 1986:15-24 oor hoe psalmdigters 'n bepaalde tema van Psalm 1 opneem en verder uitwerk).

Die wysheidsliteratuur het 'n sterk universele inslag en handel onder andere oor die lewe soos dit in die alledaagse gang van sake waargeneem word (vgl. oor hierdie literatuur, o.a. Lion-Cachet, s.j.: 110-112; Vriezen, 1966:261-265; Kaiser, 1978:165-181; Loader, 1989:684-689). Hierdie literatuur het veral te doen met empiriese waarneming en die vrug van nadenke daaroor en hou hom ook besig met die teenstrydighede van die lewe soos dit uit waarneming blyk, byvoorbeeld dat dit goed gaan met die goddeloses en sleg met diê wat reg lewe. Hiervan is die boek Job 'n voorbeeld (vgl. ook Ps. 73). Die wysheidsliteratuur hou hom verder besig met die bepeinsing oor die sin van die menslike bestaan, die sin van die gang van die natuur, die sin van voorspoed, ensovoorts, soos in die boek Prediker. Die feit dat Psalm 36 trekke van die wysheidsliteratuur vertoon en nie bloot 'n kultiese gedig is nie, het dus 'n belangrike betekenis om dié psalm in sy ware perspektief te kan sien - dit bevestig die grond om die psalm ook buite-kulties aan te wend, soos vir ' $n$ universiteitsleuse. Trouens, kultuspersoneel en wysheidsleraars het nie geïsoleerd van mekaar bestaan nie (vgl. byvoorbeeld Thomas, 1986:15-16).

Nog 'n kenmerk van die wysheidsliteratuur is dat dit aanvanklik bedoel was vir onderrig soos op skool, en daarom in terme van eenvoudige, skerp afgebakende, ongekompliseerde indelings en teenstellings redeneer. Die fokus val op 'n basiese waarheid en basiese teenstellings, sonder om die skakeringe en oorvleuelings tussen die indelings en teenstellings in berekening te bring. Hierdie feit gee perspektief op Psalm 36.

Om die teenstelling tussen die regverdige en die goddeloses in Psalm 36 in perspektief te sien, kan na Psalm 1 gekyk word. Psalm 1 is 'n psalm met wysheidskenmerke (vgl. Kraus, 1972:2). In die psalm word gese dat daar maar een ware weg is, die weg van God se Woord: dit is die weg van die reguerdige en hierdie weg is 'n weg van voorspoed. Daarteenoor staan die weg van die goddelose: dit is die weg van ondergang. Psalm 1 word algemeen deur eksegete beskou as ' $n$ inleiding tot die hele psalmbundel 
(vgl. Ridderbos, 1955:9; Kraus, 1972a:2; Childs, 1979:513) en sê dus waarom dit in kern in die psalmbundel gaan. Op die oog af lyk Psalm 1 naief en lewensvreemd. Die lewe vertoon nie so 'n enkelvoudige indeling van regverdiges en goddeloses nie; ook nie so 'n enkelvoudige verband tussen regverdigheid en voorspoed enersyds, en tussen goddeloosheid en teenspoed of ondergang andersyds, nie. Die samesteller(s) van die psalmbundel is egter nie onbewus hiervan nie - daarom word Psalm 1 onmiddellik opgevolg deur Psalm 2 wat handel oor vyandskap teen God en die koning wat deur Hom aangestel is. Psalm 3 handel oor die gemoedstemming van koning Dawid wat vir sy seun Absolom moet vlug en die volgende psalms gaan voort oor die onreg in die wêreld en die stryd daarteen. Die psalmdigters weet dat die lewe en die waarheid tog nie in eenvoudige indelings en teenstellings afgebaken kan word nie. Wanneer dit in die psalms wel so eenvoudig en skerp ingedeel word, is dit om dié bepaalde aspekte sterk te benadruk.

Nog 'n kenmerk van die wysheidsliteratuur is dat daar sterk in terme van konkrete en persoonlike voorstellinge gedink en gepraat word. Daar word byvoorbeeld van die goddelose gepraat terwyl die skrywer dit basies teen die goddeloosheid het, maar die skrywer praat vanuit die konkrete, empiriese waarneming - soos die goddeloosheid konkrete gestalte in persone en hulle optrede kry. Gierlich (1940:130-134) wys daarop dat die psalmdigters 'n voorliefde het vir personifiëring en beeldspraak en nie in abstrakte of begripsmatige terme dink of praat nie. Hierdie feit is belangrik om die antitese in Psalm 36 en die implikasies vir vandag te verstaan.

In die oorsig oor die inhoud van Psalm 36 moet gewys word op die volgende aspekte wat vir ons onderwerp van belang is:

- menslike selftevredenheid en selfgesentreerdheid;

- God regeer in liefde, geregtigheid en trou;

- $\quad$ in u lig sien ons die lig";

- gebed in bedreiging.

In aansluiting by hierdie aspekte sal ook kortliks gehandel word oor die verhouding tussen die Ou Testament en die Nuwe Testament.

\section{DIE MENS IS SELFTEVREDE EN SELFGESENTREERD}

Die eerste vers van Psalm 36 (uitgesonderd die aanhef, v.1) is problematies. Eksegete is dit oor die algemeen eens oor die hoofgedagte soos weergegee in die 1983-Afrikaan- 
se Vertaling: "In die hart van die goddelose het die opstand teen God die laaste woord." Oor die besonderhede of nuanseringe loop die menings sterk uiteen. Daar staan letterlik: Godspraak (of: influistering) van die opstand teen God (pesac) aan (of: oor) die goddelose binne-in my hart: (daar is) geen vrees (angs) vir God voor sy oë nie.

Die woord "Godspraak" (ne'um) is 'n tipiese uitdrukking by die profete as aanduiding van God se openbaring aan die profeet (vgl. Van Zyl, 1989:611; Ridderbos, 1955:310). Die uitdrukking is uitsonderlik vir die psalms; daarom wil sommige eksegete die woord verander na na $^{\mathrm{c}} \mathrm{im}$ of na'us) en vertaal met "lieflik is die opstand teen God vir die goddelose" (bv. Kraus, 1972(a):280-281). Daar is egter nie tekskritiese grond vir so 'n verandering nie.

Een verkJaring is dat die teks wil sê dat die opstand teen God vir die goddelose is wat God vir die profeet is (vgl. Weiser, 1959:206). Opstand teen God is die goddelose se opdraggewer. "Daar is geen vrees of angs (pabad) vir God voor sy oë nie"; hy steur hom nie aan God nie, hy is nie bang vir die dreiging van God se straf nie. Weiser vat die gedagte van vers 2 so saam: die stem van die sonde wat die mens in sy eie hart verneem, het vir die sondaar dieselfde gesag en mag as die stem van God by die profete. Daar is ironie en diepe erkentlikheid opgesluit in die vers: die mens wat hom in sy gewaande begrip van vryheid daarop beroem dat hy geen vrees vir God het nie en wat glo dat hy hom op hierdie manier van God se heerskappy in sy lewe kan onttrek, staan onbewus onder ' $n$ veel harder heerskappy en het 'n heeltemal ander "god" waaraan hy onderdanig is - die sonde.

Oor die algemeen verander eksegete die woorde "binne-in my hart" na "binne-in sy hart", in aansluiting by die Griekse en Siriese vertalings. So vertaal Ridderbos (1955:310): "De fluisterstem der zonde (komt) tot de goddeloze, diep in zijn hart ..." (vgl. ook Briggs, 1927). Delitzsch (1894:284) vertaal: "Eingebung des Lasters ergeht an den Gottlosen innerhalb seines Herzens."

Die Hebreeus kan egter ook so verstaan word dat dit nie 'n Godspraak aan die goddelose is nie, maar oor, of aangaande die goddelose. Dit kan dan slaan op iets soos 'n Godspraak wat die digter ontvang aangaande die goddelose. Die woord "in my hart" kan in dié rigting wys. Die 1933-Afrikaanse Bybelvertaling lui s6: "In die binneste van my hart se die oortreding aangaande die goddelose: Daar is geen vrees vir God voor sy oë nie." Du Toit (1958:1145) verklaar dit dan so: "As ek die goddelose gedrag van die kwaaddoeners aanskou en oorwceg, word ek gedwing om te glo dat daar geen vrees van God voor hul oè is nie. Die digter stel dit so voor asof die sonde as persoon hom hierdie gevolgtrekking ten opsigte van die sonde influister." 
PU vir CHO se naam, leuse en taak in die lig van Psalm 36

van God voor hul oë is nie. Die digter stel dit so voor asof die sonde as persoon hom hierdie gevolgtrekking ten opsigte van die sonde influister."

Calvyn (1970:453) sê: "Ofskoon die ware godsdiens die vroom gemoedere in die vrees van God bewaar en alle goddelose oorweginge ver hou, verhinder dit tog nie dat hulle in hulle hart duidelik sien hoe verskriklik die goddeloses woed en raas as hulle hulle nie oor God bekommer nie en hulle nie aan sy oordeel steur nie." Volgens Calvyn dui die vers nie op ongelowiges in die algemeen nie maar op verharde goddeloses.

Die antitese volgens Psalm 36 is nie soseer met die goddeloses self of met ander teenstanders nie, maar met die goddeloosheid (vgl. ook die stelling van Gierlich, 1940:130134). Trouens, Psalm 36 maak nie 'n vergelyking of 'n teenstelling tussen die goddelose en die regverdige nie, maar tussen die goddelose se gesindheid en optrede enersyds, en dié van God, andersyds. Of beter gestel - God se liefde, geregtigheid en trou in die wêreld waarin selftevredenheid, selfsug en onreg skynbaar die laaste woord het, word benadruk (v. 2-5).

\section{GOD REGEER UNIVERSEEL, EN WEL IN LIEFDE, GEREGTIGHEID EN TROU}

In vers $6 \mathrm{kom}$ 'n onverwagte wending in die psalm. Tot hier het die digter dit gehad oor 'n antroposentriese denke wat die mens in die middelpunt stel; van hier af gaan dit oor die teosentriese wat geheel en al van Godsweë bepaal word (Weiser, 1959:207). Die fokus is nou geheel en al op God. Dit is hy wat regeer, nie die korruptheid van die mens nie (Toombs, 1972:273), en God regeer in liefde, trou en geregtigheid.

Uit vers 8-9 kan afgelei word dat die digter oor die diens in die heiligdom handel (vgl. ook Ridderbos, 1955:313; Weiser, 1959:208; Kraus, 1972a:283). In vers 8-9 staan letterlik: "Daarom skuil die mensekinders onder die skaduwee van u vleuels. Hulle verkwik hulle aan die vettigheid van u huis, en $U$ laat hulle drink uit die stroom van u genietinge." Die psalm se visie oor God se optrede is egter nie tot die erediens of tot geestelike verlossing beperk nie, maar sluit God se sorg in die breedste sin in. Dit blyk uit vers 6-7. God se heerskappy omvat alles: 


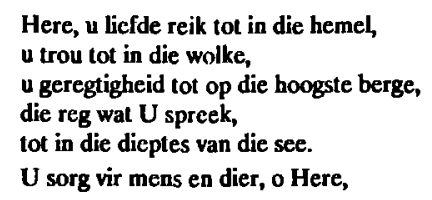

Daar is reg en sin en orde in God se skepping, die hele skepping.

Die metafoor oor die skaduwee van u vleuels simboliseer nie net die tempel nie maar ook God se beskermende sorg waarin alle mense hulle vertroue kan stel (Ps. 57:2; Ps. 63:8). Op soortgelyke wyse verwys "die vettigheid van u huis" en "die stroom van u genietinge" nie net na die eet en drink by feeste in die tempel nie, maar ook na God se oorvloedige voorsiening in die mens se behoefte in die natuur (Ps 65:10-14; Ps.78:2324).

Dat die digter se perspektief nie tot die tempel en erediens beperk bly nie maar wyer uitkring, blyk verder uit die feit dat hier nie gese word dat dit Israel is wat onder die skaduwee van God se vleuels skuil nie, maar "die mense". Die digter loof God oor sy universele goedheid. Hierdie uitkring van visie hang daarmee saam dat dit in die kultus nie net gaan om die gawes van God nie, maar ook en veral om die gemeenskap met Hom en die lewe uit Hom; Hy wat oor alles en almal is. By Hom is die bron van die lewe soos gestel in vers 10 .

\section{1 "In/deur u lig sien ons die lig"}

By $U$ is die fontein van die lewe; in $u$ lig sien ons die lig.

In Jeremia 2:13 en 17:13 word God aangedui as bron van lewende water (vgl. ook Clements, 1965:75). God is die volheid van lewe self, die lewensbron - oral waar lewe is, is dit 'n gawe van Hom. Lewe met Hom beteken vir Israel voorspoed, volheid van natuurlike goedere. 'n Mens sou God in die Ou-Testamentiese bedeling lewe kan noem soos die Nuwe Testament God liefde noem (Vriezen, 1966:345) - al dui die Ou Testament Hom nie direk met so 'n formule aan nie (vgl. Schmid, 1923:126).

Hierdie vers vorm 'n parallelisme - iets wat tipies is van Hebreeuse digwerk. In hierdie soort versvorm word in die tweede deel van die vers of versreël die gedagte van die eerste gedeelte herhaal, en wel met 'n identiese, antitetiese of aanvullende stelling (vgl. 
Verhoef, 1981:51). Hierdie parallelisme wys dat die lig wat gesien word (v. 10), lewe is en nie kennis nie (anders as in Psalm 119:105,130; Spr. 6:23) - trouens, die hele verband van die psalm bewys dit (vgl. ook Ridderbos, 1955:314, teenoor onder andere Thomas van Aquino wat aanvaar het dat selfs in die verstand daar 'n ligvonk uit God is; Gierlich, 1940:15). Lig en lewe is hier sinonieme soos in Job 33:30. Om die lig te sien, is om te lewe. Die gedagte onderliggend aan die uitdrukking is dat 'n mens by geboorte uit die donkerheid van die moederskoot die lewenslig sien (Job 3:16; vgl. Gierlich, 1940:132). Dié wat dood is, sien nie lig nie (Ps. 49:20; vgl. Taylor, 1955:190). Sonder die lig is die situasie soos voor die sesdaagse skepping - lewe is onmoontlik (Gen. 1:2). (Daar is nie uit die teks of uit die teksverband enige steun vir 'n beskouing dat Psalm 38:10 beteken om God te sien nie; vgl. hieroor bv. Smith, 1988:171.)

God is die bron van alle lig, letterlik sowel as figuurlik - alles kom van Hom af. Hy is gehul in lig (Ps. 104:2); sy gesig straal lig (Ps. 44:4; Ps. 89:16; Num. 6:25; vgl. Van der Ploeg, 1971). Hy word self enkele kere as die lig van mense of van Israel voorgestel (Ps. 27:1; 2 Sam. 22:29; Jes. 10:17; miskien Jes. 60:1; Miga 7:8; vgl. Aalen, 1973:175). Net soos die is van God meer is as net 'n neutrale of statiese wees, en sy dinamiese, beskermende en reddende teenwoordigheid aandui (Eks. 3:14; vgl. Helberg, 1988(b):292,297,298), so dui die woorde "In u lig" in Psalm 36:10 nie God se blote bestaan of teenwoordigheid aan nie, maar sy aktiewe, openbarende, heilskenkende teenwoordigheid (vgl. ook Ridderbos 1955:314). Kraus (1972(a):283) sê dit is die lig van sy aangesig (Ps 4:7; Ps. 89:16), dit wil sê die ligglans van die deus revelatus (Vergelyk ook Kraus 1972(a): LXVIII oor die onmiddellike teenwoordige openbaringsgebeurtenis in baie psalms en oor die verskil tussen die twee verskillende pole in verband met die verklaring van die verhouding tussen openbaring en erediens. Volgens die een word die openbaring byna volledig in die kultus geïntegreer, soos by Gyllenberg, en volgens die ander is die psalms wesenlik "Israel se antwoord", soos by Von Rad.)

Om in God se lig die lig te sien of deur sy lig te lewe, is meer as net die blote neutrale bestaan. Dit is ware lewe, 'n lewe van voorspoed, seèn en lewensgeluk, ook geestelike lewensgeluk (vgl. Gierlich, 1940:135, 140-141, 151; Ridderbos, 1955:314). Lig is dikwels die beeld vir geluk en voorspoed (Am. 5:18,20; Joh. 17:12; Joh. 22:28; Spr. 13:9; Klaagl. 3:2; Est. 8:16), en duisternis die beeld vir lyding en ongeluk (Jes. 8:22; Jer. 23:12; Am. 5:18,20; Ps. 23:4; Job 17:12; 18:5,6; 29:3; Klaagl 3:2). In religieusgeoriënteerde tekste word lig 'n simbool vir die heil wat deur God geskenk is (Jes. 9:1; Jes. 58:8; Ps. 18:29; Ps. 36:10; Ps. 43:3; Ps. 97:11; Job 29:31 vgl. Aalen, 1973:174; Saebo, 1971:88). 
Ten diepste gaan dit vir die digter om 'n verhuuding waarin God Hom openbaar en waarin hierdie openbarende teenwoordigheid gesoek word, 'n verhouding van persoonlike gemeenskap met God self en diensbaarheid aan Hom. Sy gawes in die erediens en die skepping is ' $\mathrm{n}$ teken hiervan. Hy is nie slegs die oergrond van alle bestaan nie (vgl. ook Eichrodt, 1967:101), maar, in gemeenskap met Hom bestaan die eintlike lewe (vgl. Weiser, 1959:209). Die openbarende teenwoordigheid van God het as resultaat dat 'n mens nie net oor God praat nie maar Hom persoonlik bely. Hierdie belydeniskarakter spruit duidelik daaruit dat die digter in vers 10 vanaf die derde persoon oorslaan na die eerste persoon: "ons" (vgl. Kraus, 1972(a):284).

Hier in Psalm 36:10 word nie gesê dat God die fontein van die lewe of die lig is nie, maar wel dat dit "by" God is. God is wel die lig en die lewe vir die mense, Hy is wel die bron van die lewe, soos die 1983-Afrikaanse Vertaling dit stel, maar Hy is dit op 'n bepaalde wyse. Alles kom van Hom af, maar dit vloei nie uit Hom voort nie. Die lig is nie 'n wesensaanduiding van God nie, maar dui uitsluitlik op die betekenis wat God vir mense het in die sin van heil en hulp. ' $n$ Teogoniese ontstaan van lig, 'n vergoddeliking en mitologisering van lig, is uitgesluit (vgl. Gierlich, 1940:177; Aalen, 1973:175,178; Saebo, 1971:89-90). Die verskil tussen Skepper en skepping word gehandhaaf.

Die stelling dat ons in God se lig die lig sien, word opgevolg deur 'n bede dat God se liefde (hesed) moet bly by dié wat Hom ken (jdc, v.11). Daar is dus 'n noue verband tussen die lig sien en God ken. Laasgenoemde is die vrug van eersgenoemde. Hierdie ken is om kennis van God te hê uit hierdie openbaring en is tegelykertyd meer as intellektuele kennis - dit is ' $n$ ken met die hart en berus op 'n persoonlike verhouding; dit sluit in om Hom te erken, Hom te soek, na sy wil te vra en volgens sy gebooie te leef (vgl. Ps. 79:6; Ps. 87:4; 1 Sam. 2:12; Jes. 1:3; Jer. 22:16; vgl. Ridderbos, 1955:315). Verder sluit dit in om op Hom te vertrou (vgl. ook Ps. 9:11). Hierdie openbaring van God is veral vergestalt in sy op-Skrif-gestelde woord (Ps. 1,19,119) en is 'n lig vir die gelowiges (Ps 119:105,130).

Gierlich (1940:3 noot 9) sê dat "lig sien" beteken om te leef en lewensgeluk te hè; ons kan dit egter alleen ontvang as God ons goedgesind is, figuurlik uitgedruk - "deur die lig van sy aangesig".

Calvyn (1970:459) wys daarop dat ons alleen die lig sien as God ons self deur sy Heilige Gees bestraal, want Johannes 1 sê dat die lig in die duisternis skyn maar dit word nie deur die mense opgemerk nie. As hulle verlig word, is dit 'n gawe van bo. Intussen bemerk slegs die gelowiges dat hulle die lig aan God ontleen het, dat hulle nie in duisternis asof begrawe sou bly nie. 
Die leemte in die mens se lewe is dus nie bloot gebrek aan kennis nie. Kennis of wetenskap as sodanig gee nie die antwoord op die mens se bestaansbehoefte nie. Wel moet daar getuig word van hierdie lig wat van God is sodat hierdie lig gesoek word.

\section{GEBED TEEN BEDREIGING}

Die lof аaл God in dié psalm word, soos reeds gesien, opgevolg met 'n gebed in bedreiging: "Laat u liefde bly by dié wat $U$ erken en u trou by dié wat opreg is van hart" (v. 11). Die maatstaf waarmee die digter mense hier groepeer, is religieus-eties: nie of iemand tot Israel behoort nie, maar of hy tot die gelowiges behoort, gelowiges wat opreg lewe.

Die digter sluit met 'n bede teen die bedreiging deur eiegeregtige en goddelose mense, 'n gebed met die sekerheid van redding deurdat dié wat altyd onreg doen, se ondergang aanbreek (v.12-13). Daar is reeds daarop gewys dat dit ten diepste om die vernietiging van die goddeloosheid gaan, eerder as om die ondergang van die goddeloses. Hier skemer ook iets daarvan deur wanneer die digter letterlik praat van die "voet van trotsheid", dit is die trotse voet. Die groot sonde van die mens is hoogmoed (Van der Ploeg, 1971:233).

Veral Christus het dit duidelik laat word dat dit om die stryd teen goddeloosheid of sonde gaan, eerder as om die stryd teen goddeloses. Die sonde het op elke mens se hart ' $n$ dodelike greep, ook op die hart van die volk van God. Daarom vra dit daagliks selfondersoek en bekering. Christus is die nuwe Adam, die nuwe mens. Hy verteenwoordig die "mensekinders" in hulle mislukking en in hulle oorwinning - in hulle mislukking deur vir hulle sondes aan die kruis te sterf, hoewel Hy self sonder sonde is; in hulle oorwinning tot nuwe mense deurdat $\mathrm{Hy}$ met sy Gees in hulle opstaan. Hy is die lig uit wie hierdie nuwe mense leef.

Met die koms van Christus verskuif die fokus geheel en al na God se verlossingswerk soos in Christus verwerklik. Ook die vraag na die seëviering van geregtigheid verskuif en kom in 'n ander raamwerk te staan. God het geregtigheid laat seëvier deurdat $\mathrm{Hy}$ sy regverdige Seun laat sterf het vir die sonde van onregverdiges wêreldwyd. Dit het gebeur sonder enige verdienste van hulle kant, uit loutere Goddelike genade. Wat die onregverdiges betref, verskuif hulle hooffokus weg van die gevoel van bedreiging en van die stryd om reg vir hulleself, hulle wat ondanks hulle sonde in die geregtigheid van Christus deel asof hulle self geen sonde gehad of gedoen het nie. Dankbaarheid 
en liefde en die begeerte om diensbaar te wees, word die drytveer van hulle lewe. Met hierdie gedagtes word dan ook aangesluit by die verhouding tussen die Ou en die Nuwe Testament.

\section{DIE VERHOUDING OU TESTAMENT - NUWE TESTAMENT}

Hier sal slegs ingegaan word op enkele algemene kenmerke wat vir ons sentrale besprekingspunt van direkte belang is.

Die feit dat die Bybel 'n Ou Testament en 'n Nuwe Testament het, sê dat daar iets is wat oud geword het en dat daar iets gekom het wat nuut is. Dit beteken egter nie dat die Ou Testament uitgedien is en deur die Nuwe Testament vervang is nie. Ook beteken dit nie dat die Ou Testament van 'n laer orde is en met 'n meer ontwikkelde orde vervang is nie. Christus self het positief geoordeel oor die Ou Testament. Hy het gesê: "Ek het nie gekom om die wet of die profete ongeldig te maak nie. Ek het nie gekom om hulle ongeldig te maak nie, maar om hulle hulle volle betekenis te laat kry" (Matt. 5:17). Christus het gekom om te vervul - daarom moet die Ou Testament en die Nuwe Testament aanvillend tot mekaar gelees word. Die Ou Testament kan nie bloot op sigself gelees word nie, want dan word die vervulling, die volle betekenis gemis. So kan die Nuwe Testament nie bloot op sigself gelees word nie, want dan hang die vervulling in die lug (vgl. Helberg, 1983:97-102). Wie nie ems maak met die Ou Testament nie, mis byvoorbeeld die verbondsbedding waarin die Nuwe Testament vloei asook die gevestigdheid in die praktiese aardse werklikheid. Gevolglik word die Nuwe Testament maklik indiwidualisties en vergeestelikend gelees.

Hier kan verder herinner word aan Calvyn (1988:1021-1043, veral 1024,1030,1037,1038). Luther het 'n skerp onderskeiding, in 'n sekere sin selfs 'n skeiding, gemaak tussen die Ou Testament en die Nuwe Testament, tussen wet en evangelie. Calvyn daarenteen het die eenheid van die Ou en die Nuwe Testament, van wet en evangelie, benadruk, met behoud van die onderskeid tussen die twee. Daarom het Calvyn in besonder 'n oop oog gehad vir die hoedanigheid van God as Skepper en Regeerder van die hele wêreld in al sy fasette, en dus ook vir gelowige wetenskapsbeoefening, Christelike wetenskapsbeoefening.

Die Nuwe-Testamentiese bedeling is nie bloot die bedeling van vervulling nie, maar is in sekere opsigte, net soos die Ou Testament, ook nog 'n bedeling van verwagting. Dit is die bedeling tussen die eerste en die tweede koms van Christus; die koninkryk het gekom maar moet ook nog kom. Hierdie bestaan is nog onvolmaak, en die konings heerskappy van God in baie opsigte onsigbaar, soos 'n koringkorrel in die grond, of 
soos suurdeeg in meel. Die gelowige se blik is vorentoe gerig, na wanneer Christus die heerskappy oor alles aan God sal oorgee; daarom voer hy sy roeping uit in hierdie vaste hoop op die toekoms, of, beter gesê, op God in die toekoms (vgl. oor die reeds en tog nog nie van die koninkryk, Ridderbos, 1972:102-104; Floor, 1981:78-80).

\section{SAMEVATTENDE GEDAGTES OOR DIE LEUSE, NAAM EN TAAK VAN DIE PU VIR CHO}

In die lig van die voorafgaande bespreking kan die vier vrae wat aan die begin gestel is, kortliks soos volg geantwoord word:

- Die naam en die leuse van die Potchefstroomse Universiteit vir Christelike Hoër Onderwys bely die eenheid van die Woord van God soos vervat in die Ou Testament en die Nuwe Testament, wat in aanvulling tot mekaar gelees moet word om die volle betekenis daarvan te begryp. Die naam en leuse sê ook dat verlossing nie net 'n mens se sogenaamde geestelike kant raak nie, maar die hele lewe - en daarom ook wetenskapsbeoefening. Christus is nie net verlossingsmiddelaar nie, maar ook die skeppings- en herskeppingsmiddelaar.

Die PU vir CHO het deur die loop van sy geskiedenis die aarde nie bloot sekulèr benader nie maar as skepping van die Skepper en Regeerder van alle dinge. Daarom is daar nie 'n gaping gesien tussen gousdiens en wetenskap, of tussen geloof en wetenskap, of tussen Skrifopenbaring en wetenskap nie (vgl. byvoorbeeld Duvenage, 1985; Helberg, 1981). Net so min is die Skrif gesien as iets wat bloot oor verlossing handel. So 'n soteriologiese benadering bied geen Skriftuurlike basis vir die mens se verantwoordelikheid in verband met onder andere die ekologie van die aarde nie en verwaarloos hierdie lewensbelangrike verantwoordelikheid (Santmire, 1985). Geloof in God bring ' $n$ verantwoordelikheid teenoor die skepping in al sy aspekte mee. Die mens is rentmeester van God op die aarde.

- Die woorde "In u lig" in Psalm 36:10 dui op God se openbarende en heilgewende teenwoordigheid, 'n teenwoordigheid wat volheidslewe skenk. Psalm 36:10 sê dus dat ons bestaan in sy volheid van God se openbaringslig af kom. Die lig wat ons hierdeur sien, sluit kennis in maar is tegelykertyd meer as intellektuele kennis en omvat die mens se volle bestaan in al sy fasette.

Die Nuwe Afrikaanse Bybelvertaling ontneem dus nie die PU vir CHO se leuse van die bestaansgrond van sy segging en betekenis nie. Inteendeel, dit laat die ryke 
betekenis van die leuse nog duideliker relief kry - dit sê trouens dieselfde as die 1933/53-vertaling, maar in ooreenstemming met sy doel om die betekenis duideliker weer te gee, word dit in ander woorde gese, in onderskeiding van die 1933/53vertaling wat 'n sterk letterlike vertaalmetode gevolg het (vgl. bv. Van der Walt, 1986; Postma, 1986:58; Van Zyl \& Swanepoel, 1972:33-34, 56-57). In die Nuwe Vertaling word wel die bestaansgrond van 'n intellektualistiese benadering van die leuse en van die Universiteit se taak uitgeskakel. Die PU vir CHO bely juis met sy leuse dat ' $n$ mens nie net ' $n$ intellektuele wese is nie en dat die onderrig dus nie net 'n intellektuele aktiwiteit is nie maar dat dit te doen het met die mens in sy volle menswees - daarom het onderrig ook te doen met die bron van die mens se menswees, God. Die Universiteit maak dus erns met God in sy openbarende en heilgewende teenwoordigheid en met sy vasgelegde openbaring as basis en rigsnoer vir so ' $n$ volheidslewe.

Genoemde gedagtes impliseer dat van dosente en studente vereis word om met hulle algehele optrede en lewenspatroon hieraan gestalte te gee. Opgeleide studente behoort 'n deeglike kennis van hulle vakrigting te hê en tegelykertyd 'n roepingsbewustheid om met hulle hele menswees diensbaar te wees.

- Die woorde van Psalm 36 waaraan die Universiteit se leuse ontleen is, kom uit 'n kultiese situasie maar is nie bloot kulties-bepaald en dus tot die erediens beperk nie. Dit kring uit oor alle grense, is waarlik universeel en is dus werklik geskik vir 'n universiteit se leuse en taak. So gesien, is die Universiteit nie sonder verband met erediens of kerk, waarby die Bron van lig volgens Psalm 36 besonderlik aansluit nie, maar kan daar ook nie sprake wees van kultiese of kerklike dominering van die universiteit of die wetenskap nie. Wedersydse belangstelling en samewerking is nodig. In aansluiting by sy leuse stel die Universiteit dit as sy taak om die skepping (natuur) en die geskiedenis self na te vors, maar om dit te doen by die lig van God se openbaring, gedagtig aan die woorde in Psalm 19: "Die hemel getuig van die mag van God, die uitspansel maak die werk van sy hande bekend. Die een dag gee die berig deur aan die ander en die een nag deel die kennis aan die volgende mee.. Die woord van die Here is volmaak: dit gee lewe" (Ps. 19:2-3,8),

- Volgens Psalm 36, en volgens die Bybel as geheel, het 'n mens se lewe in sy geheel en al sy dele, 'n religieuse, teosentriese basis: "... kennis begin met die vrees, of dien van die Here" (Ps. 111:10; Spr. 1:7) - dit veronderstel 'n besliste antitese, soos antitese met ' $n$ antroposentriess lewensbasis. Hierdie antitese is egter nie gewortel in selftevredenheid nie en is nie basies ' $n$ antitese met andersdenkendes nie - dit is 
'n antitese met die sonde, wat ook en veral in eie hart en lewe en wetenskapsbeoefening beveg moet word. Die antitese kan veral nie op ras of kleur of volkskap of kultuur gerig wees nie. 'n Nasionale of kulturele gerigtheid het wel 'n plek, maar nie geslotenheid nie. Christus het 'n ander fokus gebring, 'n ander dryfveer, 'n ander allesbeheersende doelpunt.

Uit alle oorde hoor ons dat die mens eksistensieel bedreig voel: in sy persoonlike situasie, huwelik, gesin, kerk, werk en breëre samelewing. Hy is bedreig in die politiek-staatkundige situasie asook deur kernkrag en deur ekologiese versteurings op die aardbol. Daarom voer hy 'n stryd van verdediging, van selfhandhawing. Psalm 36 bevestig dat die mens fundamenteel bedreig is, maar sê dat die bedreiging sy wortel het in die mens se verhouding tot God. Ware beskerming lê in kern daar. 'n Mens verabsoluteer gedurig die bedreiging van jou besondere situasie, en daarom ook jou stryd en jou oplossing vir dié situasie. Christus eis 'n radikaal ander instelling. Hy sê: "Dit is alles dinge waaroor die ongelowiges begaan is. Julle hemelse Vader weet tog dat julle dit alles nodig het. Nee, beywer julle allereers vir die koninkryk van God en vir die wil van God, dan sal Hy julle ook al hierdie dinge gee" (Matt. 6:32-33).

Die beheersende vraag moet dus wees: Wat is my roeping? Hoe kan ons diensbaar wees, ook in wetenskapsbeoefening?

\section{BIBLIOGRAFIE}

AALEN, S. 1973. 'Br. (In ThWAT. Stuttgart : Kohlhammer. p.160-192.)

BALENTINE, S.E. 1989. Prayers for justice in the Old Testament: Theodicy and theology. Catholic Biblical Quarterly, 51(4):597-616.

BLYE BOODSKAP (DIE). 1975. Die vier Evangelies, die Handelinge van die apostels en Psalms 1-50. Nuwe Vertaling. (1e oplaag.) Kaapstad : Bybelgenootskap van Suid-Afrika.

BRIGGS, C.A. \& E.M. 1927. A critical and exegetical commentary on the Psalms. (International Critical Commentary) Edinburgh : Clark.

BYBEL IN AFRIKAANS (DIE). 1933-53. Kaapstad : Bybelgenootskap van Suid-Afrika.

BYBEL IN AFRIKAANS (DIE). 1983. Nuwe Vertaling: Bybclgenootskap van Suid-Afrika.

CALVYN, J. 1970. De boek der Psalmen. I. Goudriaan : W.A. de Groot.

CALVYN, J. 1984. Institusie van die Christelike godsdiens. I. Potchefstroom : Calvyn Jubileum Boekefonds.

CALVYN, J. 1988. Institusie van die Christelike godsdiens. III. Potchefstroom : Calvyn Jubileum Boekefonds.

CHILDS, B.S. 1979. Introduction to the Old Testament as Scripture. London : SCM

CLEMENTS, R.E. 1965. God and temple: the idea of the divinc presence in ancient Israel. Oxford : Blackwell. 
DELITZSCH, F. 1894. Biblischer Kommentar über die Psalmen. Leipzig : Dorfling \& Franke.

DU TOIT, S. 1958. Psalms. (In Die Bybel met Verklarende Aantekeninge. Kaapstad : VPU.)

DUVENAGE, B. 1985. Christelike wetenskap as Woordgebonde Wetenskap. Potchefstroomse Studies in Christelike wetenskap J2 8. Potchefstroom : PU vir CHO.

EICHRODT, W. 1967. Theology of the Old Testament. Il. London : SCM.

FLOOR, L. 1971. Die evangelie van die Koninkryk. Pretoria : NG Kerkboekhandel.

GIERLICH, A.M. 1940. Der Licbtgedanke in den Psalmen. Freiburg im Breisgau : Herder-Druck (Proefskrif (D.D.)-Albert Ludwigs-Universitat.)

HELBERG, J.L. 1981. Die beginsel van ware wetenskap is oorgawe aan God. (In Interpretasie en oordeel. Wetenskaplike Bydraes van die PU vir CHO, Recks J1, nr.1 2(1):89-95.)

HELBERG, J.L. 1983. Verklaring en prediking van die Ou Testament. Potchefstroom : Potchefstroomse Teologiese Publikasies.

HELBERG, J.L. 1988(a). Aspekte van Gen. 1-3 en die natuurwetenskappe. Koers, 53(1):39-58

HELBERG, J.L. 1988(b). Die selfbekendstelling van God in Eksodus 3 en die betekenis daarvan vir vandag. Koers, 53 (3):280-304.

HURVITZ, A. 1988. Wisdom vocabulary in the Hebrew Psalter: a contribution to the study of "wisdom psalms". Vetus Testamentum XXXVII (1):41-51.

KAISER, W.C. 1978. Toward an Old Testament theology. Grand Rapids, Mich. : Zondervan.

KRAUS, H.J. 1972(a). Psalmen. I. (Biblischer Kommentar.) Neukirchen-Vluyn : Neukirchener Verlag.

KRAUS, HJ. 1972(b). Psalmen II. (Biblischer Kommentar.) Neukirchen-Vluyn : Neukirchener Verlag.

LION-CACHET, F.N. s.j. Boek en boodskap: Besondere Kanoniek Ou Testament. Potchefstroom : Wesvalia.

LOADER, J.A. 1989. Spreuke van Salomo. (In Verklarende Bybel. Kaapstad : Lux Verbi.)

NUWE TESTAMENT \& PSALMS. 1979. 1979-Vertaling. Kaapstad : Bybelgenootskap van Suid-Afrika.

OESTERLEY, W.O.E. 1959. The Psalms. London : SPCK.

POSTMA, J. 1986. Tipering van verskillende vertaalmetodes. (In Van der Walt, J. red. In ons eie taal die waarde en gebruik van die 1933/53 en 1983 Afrikaanse Vertaling van die Bybel. Potchefstroom : Departement Sentrale Publikasies, PU vir CHO. p. 51-60.)

RIDDERBOS, J. 1955. De Psalmen. I. (Commentaar op het Oude Testament.) Kampen : Kok.

RIDDERBOS, H. 1972. De komst van het koninkrijk: Jezus' prediking volgens de Synoptische Evangeliën. Kampen : Kok.

SAEBO, M. 1971. 'Or. (In THAT. München : Chr. Kaiser. p. 84-90.)

SANTMIRE, H.P. 1985. The travail of nature: the ambiguous ecological promise of christian theology Philadelphia : Fortress Press.

SCHMID, W.H. 1983. The faith of the Old Testament. Oxford : Blackwell.

SCHMIDT, H. 1934. Die Psalmen. (Handbuch zum Alten Testament, 15.) Tübingen : J.C.B. Mohr.

SMITH, M.S. 1988. "Seeing God" in the psalms: the background to the beatific vision in the Hebrew Bible. The Catholic Biblical Quarterty, 50(1):191-183.

TAYLOR, W.R. 1955. The Books of Psalms. (In The Interpreter's Bible. IV.) New York : Abingdon Press.

THOMAS, M.E. 1986. Psalms 1 and 112 as a paradigm for the comparison of wisdom motifs in the Psalms. Joumal of the Evangelical Theological Society, 29(1):15-24.

TOOMBS, S.T. 1972. The Psalms. (In The Interpreter's One-Volume Commentary on the Bible.) London: Collins.

TOURNAY, R.J. 1983. Le Psaume XXXVI: structure et doctrine. Revue Biblique, 90(1):5-22.

VAN DER PLOEG, J.P.M. 1971. Psalmen. Deel VIlb. (De Boeken van het Oude Testament.) Roermond : Romen \& Zonen. 
PU vir CHO se naam, leuse en taak in die lig van Psalm 36

VAN DER WALT, T. 1986. Waarom 'n nuwe Afrikaanse Bybelvertaling? (In Van der Walt, J. red. In ons eie ıaal: die waarde en gebruik van die 1933/53 en 1983 Afrikaanse vertaling van die Bybel. Potchefstroom : Departement Sentrale Publikasies. PU vir CHO. p. 71-79.)

VAN SElmS, A. 1967. Genesis. I. (De Prediking van het Oude Testament.) Nijkerk : Callenbach.

VAN ZYL, A.H. 1989. Psalms. (In Vetklarende Bybel. Kaapslad : Lux Verbi.)

VAN ZYL, A.H. \& SWANEPOEL, F.A. 1972. Waarom 'n nuwe Bybelvertaling? Pretoria : N.G. Kerkboekhandel.

VERHOEF, P.A. 1981. Melodiek van die eksegese. Kaapstad : NG. Kerk-Uitgewers

VRIEZEN, Th.C. 1966. Honfdlijnen der theologie van het Oude Testament. Wageningen : Veenman \& Zonen.

WEISER, A. 1959. Die Psalmen. (Das Alte Testament Deutsch.) Gottingen : Vandenhock \& Ruprecht. 